\title{
Творчество чингиза айтматова в контексте татарско- кыргызских литературных связей (проблемы перевода)
}

\section{Нурида Шайдулловна Насибуллина}

к. филол. н., старший научный сотрудник, Центр письменного и музыкального наследия Иститута языка, литературы и искусства им. Г.Ибрагимова АН РТ nasibullina.nur@yandex.ru

\section{Аннотация}

Данная статья посвящена анализу переводов произведений Ч. Айтматова на татарский язык. Представлен краткий обзор переводов произведений писателя с 1961 по 2018 годы, осуществленными такими татарскими переводчиками, как М. Усманов, А. Еники, Я. Халитов, Х. Сарьян, Л. Ихсанова, Р. Шириязданов, М. Харисов, М. Валиев и мн. др. Изучение проблем перевода произведений мирового писателя на иностранные языки, в том числе на татарский, до сих пор исследуется и представляет большой интерес в теории перевода и литературе.

Ключевые слова: Творчество Ч. Айтматова, литературный перевод, татарская литература, анализ перевода, теория перевода, художественный перевод, культура народов, фольклор.

\section{Creativity of Chingiz Aitmatov in the Tatar-Kyrgyz Literary Connections Context (Translation Problems)}

\begin{abstract}
This article is devoted to the analysis of translations of the works of Ch. Aitmatova in Tatar. A brief overview of the translations of the works of the writer from 1961 to 2018, carried out by such Tatar translators as M. Usmanov, А. Eniki, Yа. Халитов, X. Saryan, L. Ихсанова, Р. Шириязданов, М. Харисов, М. Valiev and others. etc. The study of the problems of translating the works of the world writer into foreign languages, including Tatar, is still being studied and is of great interest in the theory of translation and literature.
\end{abstract}

Keywords: Creativity Ch. Aitmatova, literary translation, Tatar literature, translation analysis, translation theory, artistic translation, culture of peoples, folklore.

Выдающийся писатель, философ, дипломат Чингиз Торекулович Айтматов оставил яркий след в истории цивилизации и народной памяти. Творчество писателя по праву занимает видное место не только в современной киргизской, но и во всемирной литературе. 
Чингиз Айтматов - сын двух братских народов мира - киргизского и татарского. Его творчество, его дипломатическая, общественная деятельность, получившие международное признание, являют собой яркий пример того, как много могут сделать для человечества представители немногочисленных народов. Сам он неоднократно бывал в Казани, говорил потатарски, знал татарскую литературу, общался с писателями. По его собственным словам, питал к Татарстану «глубокие родственные чувства». Его мама - Нагима Хамзиевна - была татаркой, дочерью одного из богатейших людей Прииссыккулья рубежа XIX - XX веков, купца Хамзы Абдувалеева из рода Ишманов.

В начале XXI века мы вновь обращаемся к проблематике сохранения традиций и обычаев своих народов, преумножения их богатого культурного наследия. Плодотворная жизнь Ч. Айтматова для нас должна быть призывом поддерживать языки, литературу, традиции всех народов, сохранять многоцветье и многообразие культур. Тема самосохранения этносов весьма актуально звучит сегодня в национальных республиках России.

Ч. Айтматов, прекрасно владевший русским и киргизским языками, одинаково свободно писал на обоих языках, хотя был уверен, что лучше писать на родном языке, потому что соотечественники лучше принимают и понимают их.

Произведения Ч. Айтматова, издаваясь большим тиражом на русском языке, получали прямой выход на многомиллионную аудиторию. С русского языка переводились на 180 языков мира, переиздавались в 127 странах мира, стали классикой мировой литературы.

В произведениях Ч. Айтматова параллельно проистекают две сюжетные линии: одна - это линия устного народного творчества и другая - описание реальной действительности. Они дополняют и укрепляют друг друга. Учитывая эти особенности, татарские переводчики, выбрав из сюжетов произведений писателя отдельные легенды, предания, рассказы, песни, сказки и пленительные фрагменты, переводили и публиковали их отдельно от самого произведения. У татарского читателя была хорошая возможность читать произведения писателя, в большом или маленьком объеме, на страницах газет и журналов или в отдельных изданиях в переводе на татарский язык.

В XX веке татарская школа художественного перевода как неотъемлемая часть всесоюзной переводческой школы развивалась успешно и имела талантливых переводчиков, благодаря которым татарский читатель получал прекрасную возможность читать на своем родном языке произведения выдающихся писателей классической и современной мировой литературы. В этом деле велика заслуга таких известных профессиональных переводчиков и мастеров татарской литературы, как Р. Даутов, Я. Халитов, Э. Нигъматуллин, К. Минебаев, T. Нурмухамметов, А. Хасанов, Ш. Максудова, Ф. Гайнанова, Н. Валитова, Л. Назмиева, 
Ф. Миңнуллин, Я. Шамсетдинов, С. Адхамова, Н. Арслан, А. Исхак, М. Ногман, М. Хусаенов, Т. Айди, Х. Аюпов, Л. Хәмидуллин, А. Рәхимова и других.

Переводами произведений Ч. Айтматова на татарский язык большей частью занимались известные ученые, талантливые писатели и поэты, такие как М. Усманов, А. Еники, Я. Халитов, Х. Сарьян, Л. Ихсанова, М. Харисов, Р. Шириязданов, М. Валиев и др.

Профессиональные переводчики занимались переводами независимо от различных знаменательных дат и юбилеев, касающихся Ч. Айтматова. С точки зрения исторических этапов перевода произведений на татарский язык можно выделить два самостоятельных периода: советское время (60-90-е годы) и постсоветский период (с 1991 года по настоящее время). В первом периоде в основном переводились произведения писателя, в которых наиболее бросающимися в глаза являлись гуманистические мотивы, общечеловеческие ценности. Надо отметить, что рассказы Ч. Айтматова не принесли ему большой славы. Только после создания повестей он прославился как писатель, владевший новым стилем. Повесть «Джамиля», написанная писателем во время учебы в Москве, полностью перевернула писательскую судьбу: написанная на киргизском языке и переведенная на русский язык, она принесла писателю мировую славу. Это дало возможность Ч. Айтматову раздвинуть рамки критериев советской литературы, приступить к проработке не свойственных советской литературе тем. Повесть «Джамиля» стала известна и обрела любовь у широкого круга читателей разных стран и континентов, вошла в число самых лучших произведений современности. За короткое время она была переведена на 35 языков и издана тиражом более 500 тысяч экземпляров. Востребованность повести объяснялась тем, что она отвечала современному литературному вкусу и во всех отношениях обогащала литературу, принесло своему автору мировую славу.

В первый раз за рубежом повесть была переведена весной 1959 года: на перевод французского писателя Луи Арагона получил высокую оценку литераторов и был издан с превосходным, содержательным предисловием. Луи Арагон, назвал эту повесть «лучшей поэмой о любви» [15: 4]. Перевод, предисловие и признание произведения прославили Ч. Айтматова, обрели большую славу и широкое признание у ученых, литераторов и критиков Европы. Вслед за Луи Арагоном произведениями Ч. Айтматова заинтересовались многие переводчики.

Первые переводы произведений Ч. Айтматова на татарский язык были осуществлены в начале 60-х годов прошлого столетия: это повести «Джамиля», (1961), «Первый учитель» (1963), «Тополек мой в красной косынке» (1965).

Повесть «Джамиля» была переведена с киргизского языка на татарский М. Усмановым в 1961 и 1965 годах, отрывок был опубликован в журнале «Азат хатын» [10] и в газете «Социалистик

\section{Year 4/ 2020, Volume-4, Issue-1 | www.ispecjournal.org}


татарстан» [8], отдельной книгой повесть вышла в 1962 году [9], повторно издана в 1965 году [5].

Перевод М. Усманова повести «Джамиля» вызвал затруднение у рецензента А. Гилязова. Он работал с киргизским оригиналом. Это позволило М. Усманову добиться того, что отдельные эпизоды звучат сильнее на татарском, чем на русском. [16: 270]. Перевод «Джамили» М. Усманова на татарский язык отличается от многих художественных переводов. Переводчик поняв большую часть особенностей и тонкостей художественного произведения и законы творчества и перевода, смог их сохранить в татарском тексте произведения. По мнению ученого, перевод произведения имеет как достоинства, так и недостатки, но, на наш взгляд, в общем переводчик добился успеха в сохранении национальных особенностей произведения.

Вслед за М. Усмановым татарские писатели и переводчики, вдохновившись его работой, стали переводить на татарский язык лучшие произведения писателя: «Первый учитель» («Беренче мөгаллим», 1965, А. Еники), «Материнское поле» («Анам кыры», 1965, Я. Халитов), «Тополек мой в красной косынке» («Кызыл яулыклы гүзәлкәй генәм» (1965, Х. Сарьян), «Верблюжий глаз» («Дөя күзе», 1976, Я. Халитов), «Прощай, Гульсары!» («Бәхил бул, Гөлсары!», 1976, Я. Халитов), «И дольше века длится день. «Бер көн - бер гомер», 1990, Р. Шириязданов), «Белое облако Чингизхана» «Чыңгызханның ак болыты», 2016, М. Валеев).

Через год после перевода повести «Джамиля» на татарский язык была переведена повесть «Первый учитель». Повесть сначала была опубликована в журнале «Совет әдәбияты» в переводе с русского языка А. Еникием [6: 71], издана в 1965 году [5]. А. Гилязов, оценивая труд переводчиков произведений киргизского писателя с русского на татарский язык, упрекнул классика татарской литературы за то, что тот вольно обошелся с текстом оригинала: «Писатель А. Еники накрыл собой писателя Ч. Айтматова». Рецензент выражает недовольство тем, что переводчик пренебрегает волей автора, внося изменения не только в структуру текста, но и на уровне стиля [16: 270].

После публикации повестей «Джамиля» и «Первый учитель» перевод и издание произведений Ч. Айтматова в татарской литературе становится традицией. Каждое новое произведение писателя, переведенное татарскими переводчиками, тотчас публикуется в газетах и журналах. По инициативе издательств они выпускались в виде отдельных книг или в виде сборников произведений.

В советские времена самыми плодотворными переводчиком произведений Ч. Айтматова на татарский язык был редактор Татарского книжного издательства Я. Халитов. Им были переведены на татарский язык три произведения писателя: повести «Материнское поле», «Верблюжий глаз» и «Прощай, Гульсары!». В 1965 году перевел повесть «Верблюжий глаз» с русского языка на татарский и опубликовал её в газете «Социалистик Татарстан» [8]. Повесть

\section{Year 4/ 2020, Volume-4, Issue-1 | www.ispecjournal.org}


«Материнское поле», написанная Ч. Айтматовым на киргизском языке в 1963 году была опубликована в журнале «Азат хатын» [2], а в 2004 году в журнале «Мирас» [1]. Сборник повестей была издана в 1976 году [12].

В 1965 году в Татарском книжном издательстве увидел свет сборник произведений Ч. Айтматова: в него были включены переводы А. Еники, Я. Халита, М. Усманова, Х. Сарьяна [5]. А. Анализируя перевод Я. Халитова повести «Материнское поле», А. Гилязов обращает внимание на бережное отношение переводчика к слову писателя, подмечает языковые шероховатости [16: 270]. Высоко оценивая качество перевода Х. Сарьяна повести «Тополек мой в красной косынке», рецензент не преминул указать, что порой диалоги звучать чисто порусски. Положительно отнесся А. Гилязов и к использованию автором диалектизмов. Рецензент посоветовал сделать соответствующие пояснения на уровне сносок. В целом, А. Гилязов посоветовал Х. Сарьяну сократить текст, проанализировав повторы. С сожалением писал о том, что этот переводчик не ощутил музыку, заключенную в названии, отсюда и разночтения в тексте. [16: 270]. Всякий перевод нуждается в тщательном анализе качества, достижений и оплошностей. Также требуется выявление переводческих закономерностей при передаче авторской идеи.

До 1965 года Ч. Айтматов больше писал на киргизском языке. Первая повесть писателя, написанная на русском языке, - это «Прощай, Гульсары!», опубликована в журнале «Новый мир» в 1966 году. «Я пишу свои книги на киргизском и русском языках. Если книга написана вначале на киргизском языке, я её перевожу на русский, и наоборот. При этом я получаю глубочайшее удовлетворение от этой двусторонней работы. Это чрезвычайно интересная внутренняя работа писателя, ведущая, по моему убеждению, к совершенствованию стиля, к обогащению образности языка», - пишет Ч. Айтматов [7:110].

В 1981 году М. Харисов перевел отрывок из романа «Жырчы Раймалы ага» и опубликовал в газете «Татарстан яшьләре» [11].

Другой этап творчества писателя начинается с первого его романа «И дольше века длится день» («Буранный полустанок»). Этот роман впервые был опубликован в 1980 году в журнале «Новый мир» и был удостоен Государственной премии СССР (1983). В 1983 году отрывок из романа перевел М. Харисов и опубликовал в том же году на страницах газеты «Социалистик Татарстан» [4]. В виде самостоятельной книги роман был издан в 1985 году в переводе Рима Шириязданова под названием «Бер көн - бер гомер» [3].

В 1990 году в журнале «Знамя» была опубликована «повесть к роману» - «Белое облако Чингисхана», впоследствии вошедшая в состав романа. В 2018 году по случаю 90-летия со дня рождения писателя в Казани в издательстве «Мәгариф-Вакыт» вышла в свет повесть Ч. Айтматова «Белое облако Чингисхана» [14], переведенная на татарский язык известным 
поэтом, заслуженным деятелем РТ, лауреатом Республиканской премии им. М. Джалиля М. Валеевым. Пытаясь высказать на татарском языке почти то же самое, что было сказано на языке оригинала, он представил возможность читателю почувствовать очаровательную прелесть и глубину души Ч. Айтматова. Данный труд является очень важным и показательным в плане взаимного проникновения культур на Евразийском пространстве, еще одним шагом в развитии наших народов.

Повесть «Белое облако Чингисхана» впервые была опубликована в журнале «Безнең мирас» [13] в 2016 году и сразу же привлекла к себе внимание широкого круга читателей актуальным и современным звучанием. М. Валеев как переводчик и знаток двух культур, двух национальных традиций, интуитивно чувствует различия между системами. Ему виднее, какой из вариантов сохранить - родной или неродной. Выбор лексики подчинен стремлению переводчика донести до сознания читателя все национальное своеобразие, познакомить читателя с национальной культурой, национальными традициями именно через художественный текст. Переводчик, работая над текстом, из-за отсутствия подходящих эквивалентов сохраняет тюркизмы как механические сигналы и вставки.

Нужно заметить, что в Татарстане переводились и издавались не только художественные произведения писателя, но и его произведения в других жанрах, такие как публицистические статьи, очерки и его знаменитый роман «Плаха». Театральные коллективы порадовали новыми постановками по его произведениям. Ч. Айтматов вернулся на камаловскую сцену в спектакле Дамира Сиразиева «Плаха» («Ахырзаман», 1987) по пьесе драматурга М. Гилязова. Спустя 31 год после «Плахи» ТГАТ им. Г. Камала открыл свой 113 сезон постановкой спектакля по роману Ч. Айтматова «И дольше века длится день...». Создатель спектакля режиссер и драматург Ильгиз Зайниев, соединил несколько временных и художественных пластов, притчевость и реализм.

Как показало исследование, большая часть переводов произведений Ч. Айтматова осуществлена в советский период, что вполне естественно: в те годы писатель был в расцвете сил, на вершине мировой славы и в ореоле любви и почитания своих многомиллионных читателей. Переводы произведений Ч. Айтматова на татарский язык, начатые еще в 60 -е годы прошлого столетия, в последующем стали восприниматься как часть татарской литературы и заняли свое особое место. Причину такого необычного явления мы видим в единстве народов большой страны, в близости культур, в социальных и политических факторах, объединявших и укреплявших литературные связи. Нужно признать, что в советское время уровень и степень литературных связей развивались стремительно и были прочными. И это было важным фактором в литературной среде Татарстана для перевода художественных произведений писателя. 
Подводя итог вышесказанному, еще раз отметим, что Ч. Айтматов - мастер художественной прозы, которого читали люди всего земного шара, а его творчество является достоянием не только кыргызской, но и мировой литературы. Изучение проблем перевода произведений мирового писателя на иностранные языки, в том числе на татарский, все еще остается открытым, и данная проблематика представляет большой интерес для теории и практики перевода, литературоведения.

\section{Источники}

1. Айтматов Ч. Анам кыры /Я. Халит тәрж. //Мирас. - 2004. - №11; 2005. - №5. Б. 136-142.

2. Айтматов Ч. Анам кыры. Повесть /Я. Халит тәрж. //Азат хатын,1963. -№11, №12; 1964. - №1, №2.

3. Айтматов Ч. Бер көн - бер гомер: Роман /Тәрж. Рим Шириязданов. - Казан: Татар. кит. нәшр., 1990. - 287 б.

4. Айтматов Ч. Әбүталип: «Буранлы станциясе» дигән романнан өзек. /М. Харисов тәрж. // Соц. Татарстан, 1983, 21, 23, 24 авг.

5. Айтматов Ч. Повестьлар. - Казан: Татар кит. нәшр., 1965. - 314 б.

6. Айтматов Ч. Беренче мөгаллим. Повесть /Ә. Еники тәрж. //Совет әдәбияты,1963. №6. - Б. 71-111.

7. Айтматов Ч. В соавторстве с землёю и водою... Очерки, статьи, беседы, интервью. Фрунзе: Кыргызстан, 1978. 408 с.

8. Айтматов Ч. Дөя күзе. Повесть /Я. Халитов тәрж. // Соц. Татарстан, 1965, 31 окт., 4 нояб.

9. Айтматов Ч. Жәмилә. Повесть /Кыргызчадан М. Госманов тәрж. // Соц. Татарстан.1962, 4 июль.

10. Айтматов Ч. Жыр. «Жәмилә» повестыннан өзек. М. Госманов тәрж. //Азат хатын. 1961. - №8. - Б. 10-13.

11. Айтматов Ч. Жырчы Раймалы ага: /Яңа романнан өзек /М. Харисов тәрж. //Татарстан яшьләре. - 1981, 8, 10, 12, 15 дек.

12. Айтматов Ч. Повестьлар: Бәхил бул, Гөлсары! Анам кыры. Дөя күзе. /Я. Халитов тәрж. - Казан: Татар.кит. нәшр., 1976. - 320 б.

13. Айтматов Ч. Чыңгыз ханның ак болыты: романга бәян. М. Вәлиев тәрж. //Безнең мирас. - 2016. - № 8-12; 2017. - № 1, 2, 4.

14. Айтматов Ч. Чыңгыз ханның ак болыты: Бәян / Тәрж. М.Вәлиев. - Казан: МәгарифВакыт, 2018. - 151 б.

Year 4/ 2020, Volume-4, Issue-1 | www.ispecjournal.org 
15. Арагон Л. Самая прекрасная в мире история о любви: (Предисл.) Айтматов Ч. «Джамиля» / Луи Арагон. - Фрунзе, 1988. - 74 с.

16. Хабутдинова М. Личность и творчество Чингиза Айтматова в оценке татарского писателя Аяза Гилязова // Филология и культура, 2013. - № 2 (32). 